\title{
TEMPORARY MARRIAGE: A COMPARISON OF THE JEWISH AND ISLAMIC CONCEPTIONS
}

\author{
YEHEZKEL MARGALIT \\ Senior Lecturer of Law, Netanya Academic College and Bar-Ilan University \\ The contents of this article were originally published as part of the chapter "Temporary Marriage-A Possible Solution to the \\ Problem of the Agunah?" in Yehezkel Margalit, The Jewish Family: Between Family Law and Contract Law (Cambridge: \\ Cambridge University Press, 2017), 106-34. Portions of the chapter are reprinted here by permission of the publisher (all rights \\ reserved) and the author with minor modifications to conform with JLR style.
}

\begin{abstract}
The Jewish marriage differs from the Catholic Christian marriage, which is an institution surrounded by the halo of a holy sacrament that cannot be nullified. It also differs from the Islamic marriage, which is closer to a legal agreement than to a sacrament, wherein the husband alone may annul the marriage, either unilaterally or by mutual consent. This is especially true of the Shi'ite marriage-the muta-which may be annulled without any divorce proceedings at a predetermined date. In this article, I present a little-known possible halakhic stipulation: temporary marriage. I consider its roots and the different applications in Talmudic sources. An example of the Babylonian application of this conditional marriage is the cry by important Babylonian amoraim, "Who will be mine for a day?" In this unique case, some of the halakhic authorities rule that there is no necessity for a get in order to terminate the marriage. I consider the early halakhic rulings on these cases and the modern version of this stipulation, which was also rejected by modern halakhic authorities. I also offer a comparative study of a possible parallel to the marriage for a predetermined period, the Shi' ite temporary marriage, which is intentionally restricted to an agreed period of time and does not require divorce to annul it. I conclude my discussion by revealing the possible common roots for the Jewish temporary marriage and the Shi' ite temporary marriage in ancient Persian law.
\end{abstract}

KEYWORDS: temporary marriage, Jewish law, Islamic law, family law, contract law, muta, conditional marriage, Persian law, Muhammad, Catholic Christian marriage

\section{INTRODUCTION}

Jewish marriage has always been a shining example of a strong and stable family cell. It differs from the Catholic Christian marriage, which is an institution surrounded by the halo of a holy sacrament that cannot be nullified, even with the agreement of the two partners: "Therefore what God has joined together, let no man put asunder." It also differs from the Islamic marriage, which is closer

I Mark io:9. See also Phillips Roderick, Putting Asunder: A History of Divorce in Western Society i 5-30, 34-9 (i988); John Witte, From Sacrament to Contract: Marriage, Religion, and Law in the Western Tradition (1997); Zeev Falk, Nissuin VeGirushin: Tikunim BeDini Mishpaha beYahadut Ashrenaz veTzarfat [Marriage and Divorce: Reforms in the Family Life of German-French Jewry] inff, 55ff (I96I). A note on translation: 
to a legal agreement than to a sacrament, ${ }^{2}$ wherein the husband alone may annul the marriage, either unilaterally or by mutual consent. ${ }^{3}$ This is especially true of the Shi'ite marriage-the muta $^{4}$ - which may be annulled without any divorce proceedings at a predetermined date. Between these two extremes is the Jewish marriage, which may be annulled under specific circumstances or by the agreement of both partners. ${ }^{5}$

The marriage depicted in the Written Law, or the Torah, the central reference of Judaism, consisting of the five books of the Hebrew Bible that were given by G-d to Moses (hereinafter "the Written Law"), is similar to the Muslim marriage. The husband alone has the right to dissolve the marriage, and the wife can neither initiate nor demand a divorce. ${ }^{6}$ However, the decrees of

Translations from Hebrew are provided by the author. Translations from Arabic were performed with the assistance of Mr. Uri Yamin.

2 Compare the conclusions of the following articles and books in Hebrew: Shlomo D. Goitein \& Aharon Ben Shemesh, Islamic Law in the STate of Israel 2 I 8 (I957) ("the marital bond is a civil contract between two parties"); Yaakov Meron, Moslem Law in Comparative Perspective i 77 (200I) ("Marriage in Islam is a contractual agreement."); Guy Behor, Between Vision and Reality: Law in the Arab World 270 (2002) ("Under Islamic law, the marriage contract is a commercial contract, which is entered into by an offer and the acceptance of the offer and any disputes are settled under contractual law (majles), i.e., place and time, between the woman's guardian and her future husband.”). This statement is quoted also by the president of the Shari'a appeals court in Israel, his honor the Quadi Sheikh Tavik al-Aslia in T.P. (B.S.) I40/83 The State of Israel v. Amar ben Mehusan id al-Tsaria, P.M I986(2) 336, 346 (I985). This approach is reflected in legislation-specifically in paragraph 35 of Ottoman family law, which states that "Marriage is initiated by a proposal and the acceptance of the proposal either by the sides or by their representatives." Similarly, paragraph 2 of the Jordanian law governing personal status defines marriage as "a legal contract between a man and a woman with the aim of establishing a family and bearing children." For a comprehensive discussion of the Islamic conception of marriage, see HAMMUDAH ABD AL Ati, The Family Structure in Islam 50-64 n.95 (I977). For a discussion as to whether the Islamic marriage is a contract or a sacrament, along with a comparison of the Jewish and Christian approaches to marriage see ABD AL ATI, supra, at 56-59.

3 For a comparison of the Islamic approach with the different Christian approaches-Catholicism emphasizes the sacramental nature of the marriage while Protestantism is less rigid and far more flexible-see Theodor von KIPP \& Martin Wolff, Das Familienrecht [Family Law] ir4 (1923). For a more detailed account, see Dagmar Coester-Waltjen \& Michael Coester, Formation of Marriage in Persons and Family, in InternationaL Encyclopedia of Comparative Law vol. 4, 6 (Mary A. Glendon ed., I997).

4 For a discussion of the husband's ability to annul a marriage at any time without his wife's agreement, even if the marriage has been consummated, see Ziba Mir-Hosseini, Marriage on Trial: A Study of Islamic Family Law: Iran and Morocco Compared i65 (I993). For this unique type of marriage, which is problematic because it is closer to institutionalized prostitution than to institutionalized marriage, see Willi Heffening, Mut'a, in ENCYCLOPAEDIA OF IsLAM vol. 7, 757-59 (C.E. Bosworth et al. eds., I960), and more extensively my discussion below.

5 See Benzion Schereschewsky, Dine Mishpahah [Family Law in Israel] 279 (4th ed., I993); 6 Encyclopedia Talmudit [TAlmudic Encyclopedia] 354 (Shlomo Y. Zevin et al. eds., I954). For a legal disagreement over whether halakhic marriage is a normal contract, which is the opinion of judge Haim Cohen, or a special contract, in accordance with Judge Moshe Zilberg's ruling, see Israeli High Court 337/62 Rizenfeld v. Jacobson, I7 PD I009, I026-27 (I963). For a historical sketch from the development of Jewish marital laws to Christian sacramental marriage laws, see Michael L. Satlow, Slipping Toward Sacrament: Jews, Christians and Marriage, in Jewish Culture And Society Under the Christian Roman Empire 65 (Richard Kalmin \& Seth Schwartz eds., 2003).

6 For a discussion of a woman's right to initiate her divorce, see the various articles in 4 Dine IsRael (I973); Avishalom Westreich, The Wife's Right to Divorce in Jewish Law: History, Dogmatics and Hermeneutics, 62 Journal of Jewish Studies 340 (20II); Lena Salaymeh, Every Law Tells a Story: Orthodox Divorce in Jewish and Islamic Legal Histories, 4 UC IRvine Law Review I9 (2014). For the possibility of finding sources, at least in the Palestinian Talmud and in Palestinian tradition, that a woman may, in principle, introduce a condition at the time of the marriage that if she should hate her husband, he would be forced to divorce her, just as he could divorce her if he hated her, see my discussion in Yehezkel Margalit, The Jewish Family: Between Family Law and CONTRACT Law 68-IO5 (2017). 
Rabbenu Gershom Meor ha-Golah (c. Io०० CE), equated the wife's position with that of her husband, and the husband could no longer divorce his wife against her will, but both sides had to agree to the divorce. In other words, just as a marriage requires that both parties agree to it of their own free will, from that time onward, the dissolution of a marriage also required the consent of both parties. ${ }^{7}$ I point out that this is not substantive equality, but rather formal equality; as experts in different aspects of Jewish family law point out, the definitions of unfaithfulness that are a sufficient basis for the dissolution of a marriage, the justifications for divorce, and the methods of compelling divorce, are not symmetrical, with the husband's position far stronger than that of his wife. ${ }^{8}$

Moreover, a woman's status in a Jewish marriage is much worse when her husband obstinately refuses to grant her a divorce or her brother-in-law refuses to carry out halitzah (the process by which a childless widow and a brother of her deceased husband may avoid the obligation of a levirate marriage) in order to release her from a levirate marriage. As is explored at length elsewhere, 9 there has been considerable discussion regarding the source of the problem of the woman's status and possible solutions for this unique situation of levirate marriage and of the husband's refusal to grant a divorce, which in the opinion of many halakhic authorities is the most problematic and difficult halakhic issue in general, and in family law in particular.

In my previous research, ${ }^{\mathrm{IO}} \mathrm{I}$ explored also the use of contractual devices, such as conditional marriage and prenuptial agreements, to, inter alia, deal with, or at least lessen, the dismal plight of the agunah (Jewish chained woman). Throughout that research, I also tried to overcome the main halakhic obstacle to using contractual mechanisms, the well-known Talmudic dictum that "there is no conditional marriage." With this background in mind, in this article I take the issue one step farther and explore a unique contractual stipulation that may be perceived as a form of conditional marriage: the temporary marriage. ${ }^{\text {I }}$ As opposed to my previous writing in this field,

7 See Rabbeinu Asher, Resp. ha-Rosh ch. 42, s.v. “dayo" (I954). For confirmation of the effectiveness of this decree and its wide acceptance in different communities, see, for example, Rabis Nissim ben Reuven Girondi (the RAN) RESP. HA-RAN ch. 38 (I950). For a summary of the different opinions regarding this decree, see I7 TALMUDIC ENCYClopedia 378 (Shlomo Y. Zevin et al. eds., I990); SCHeresChewsky, supra note 5, at 280-8I.

8 For criticism of the religious marital structure in general, and the Jewish structure in particular, see Zvi H. Triger, The Gendered Racial Formation: Foreign Men, “Our” Women, and the Law, 30 Women's Rights Law Reporter 479 (2008-2009); Triger, Freedom from Religion in Israel: Civil Marriages and Cohabitation of Jews Enter the Rabbinical Courts, 27 Israel Studies Review I (2012); Triger, "A Jewish and Democratic State": Reflections on the Fragility of Israeli Secularism, 4I Pepperdine Law Review ro9i (20I4); Ruth Halperin-Kaddari \& Yaacov Yadgar, Between Universal Feminism and Particular Nationalism: Politics, Religion and Gender (In)Equality in Israel, 3 I Third World Quarterly 905 (20IO), and more extensively Ruth Halperin-Kaddari, Women in IsRAel: A STATE OF THEIR OWN (2004). For a discussion of the different halakhic aspects of the refusal to grant a get, see, for example, Rachel Levmor, Pre-Nuptial Agreements with the Aim of Preventing the Husband's Refusal to Give a Get, 23 Shnaton ha-Mishpat ha-Ivri [Annual Journal of the Institution for Research in Jewish Law] I27, I44-45 (2005), and all the other references discussed in the chapter 4 of Margalit, supra note 6.

9 MARgalit, supra note 6.

Io $I d$. at chapter 4 .

I I For the claim that there is nothing in Jewish law to prevent a temporary marriage, either for a period of days or months, or with a view to dissolving it at an unspecified future date, see Haim Cohn, Jewish Law in IsRaeli JuRISPRUdenCE 16 (1968); Bernard Meislin, Jewish Law of Marriage in American Courts, i I Journal of Family LAW 27I, 275 n.I3 (I97I-I972). 
which has been written almost entirely from the standpoint of the dogmatic method of halakhic research, ${ }^{\mathrm{I} 2}$ this article focuses more on the historical method. ${ }^{\mathrm{I} 3}$

In this article I illustrate Talmudic sources of the Jewish temporary marriage and trace its influence on halakhic rulings, on the responsa literature, and on the rulings of the rabbinical courts. I first analyze the Talmudic sources regarding "Who would be mine for a day?" which, in the eyes of many commentators and scholars, is a classic Talmudic application of a temporary marriage. I next discuss the Shi'ite temporary marriage for pleasure, its historical sources, its modern applications, and its influence on Jewish and Karaite responsa. I then explore the common roots of the Talmudic temporary marriage and the Shi'ite marriage for pleasure in ancient Persian law.

\section{MAN HAVYA LE-YOMA? (WHO WILL BE MINE FOR A DAY?)}

In exploring Talmudic sources that are relevant to this discussion, I found a puzzling-and astonishing-issue in the Babylonian Talmud. There are two parallel sources that may perhaps serve as evidence for the validity of a temporary marriage that is agreed upon at the time of the marriage ceremony itself. Such marriages are dissolved by a get (religious divorce), and according to some of the authorities discussed above, a get itself may not be necessary for dissolving the marriage. I am referring to the discussion of kiddushin lezman (temporary marriage) evoked by the appeal of Rav and R. Nahman, two of the most important Babylonian amoraim (the Talmudic sages, or Jewish scholars, of the period from about 200 to $500 \mathrm{CE}$ ): "Who will be mine for a day?" ${ }^{4} 4$ Below is the text:

Whenever Rav came to Darshis, he would announce: Who would be mine for a day? Whenever

R. Nahman ${ }^{\left[{ }^{5}\right]}$ would come to Shekunziv he would have it announced: Who will be mine for a day? ${ }^{\left[{ }^{[6]}\right.}$

i See Menahem Elon, Jewish Law: History, Sources, Principles (Bernard Auerbach \& Melvin J. Sykes trans., I994); Elon, Jewish Law Cases and Materials (I999), and more specifically Elon, More About Research into Jewish Law, in Modern Research in Jewish Law 66 (Bernard S. Jackson ed., I980). For the historical-dogmatic standpoint of his research books, see Ze'ev W. Folk, What Is "Jewish Law"? A Review of Jewish Law: History, Sources, Principles-Ha-Mishpat Ha-Ivri by Elon Menachem. Jewish Publication Society, I994, I I JouRNAL OF LAW AND ReLIGION 835 (1994). For other possible methods of halakhic research, see Izhak Englard, Research in Jewish Law: Its Nature and Function, in Modern Research in Jewish Law 2I (Bernard S. Jackson ed., I980); Haim H. Cohn, The Methodology of Jewish Law-A Secularist View, in Modern Research in Jewish Law, supra, at i23; Boaz Cohen, Jewish and Roman Law: A Comparative Study Vol. i vii-xxvii (I966).

I3 For a seminal writing in the historic method of halakhic research, see Shalom Albeck, Law and History in Halakhic Research, in Modern ReSEARCH IN Jewish LAW, supra note I2, at I, and the various publications of Chaim Soloveitchik. For work supporting Albeck's method, see Baruch Shiber, The Albeck System in Talmudic Research, in Modern Research in Jewish Law, supra note i2, at I I2. See also Peretz Segal, Jewish Law During the Tannaitic Period, in An Introduction to the History and Sources of Jewish Law ioi, I 37 (Neil S. Hecht et al. eds., 1996).

i 4 Babylonian Talmud, Yoma i 8b; Babylonian Talmud, Yevamot 37b. For a clarification of the exact wording of the text, which is relevant to the issue of "Who will be mine for a day?," see, for example, Ерhraim E. Auerbach, Hazal Pirkei Emunot ve-Deot [The Sages: Their Concepts and Beliefs] 422 n.28 (I969), and the variants quoted by 2 Dikdukei Sofrim ha-Shalem on Tractate Yevamot 33-34 (Avraham Lees ed., I983), with the wealth of authorities quoted in the latter work.

I 5 In the Munich manuscript we find his full name, "Rav Nahman bar Yitzhak," even though this addition is not found in the manuscript editions of Yevamot. For an attempt to identify the sage, see Yaakov Elman, Returnable Gifts in Rabbinic and Sasanian Law, 6 Irano-JudAiCA I39, I 53 n.29 (2008).

I6 In the version in Tractate Yevamot, Rivan and other early authorities, as well as the manuscripts, prefer (yome, or "days"), as do Rashash and Rashi. 
But has it not been taught: No man should marry a woman in one country and then go and marry a woman in another country lest they < their children > marry one another, with the result that a brother would marry his sister or a father his daughter, and one would fill all the world with bastardy to which the scriptural passage refers: And the land became full of lewdness? - I will tell you: <The affairs of $>$ the Rabbis are wellknown. But did not Rava say: If one has proposed marriage to a woman and she has consented then she must await seven clean days? - The Rabbis informed them before by sending their messenger earlier. Or, if you like, say: They only arranged for private meetings with them, because "You cannot compare one who has bread in his basket with one who has no bread in his basket.” ${ }_{17}$

The Talmud is amazed that the sages allowed themselves such behavior, as their conduct violates a ruling in a beraita (external Mishnah, i.e., a tradition in the Jewish oral law not incorporated in the latter), which forbids marrying a woman in one place and then leaving her to reside in another place. As R. Eliezer ben Yaakov, in the abovementioned Talmudic passages, points out, this is because of the danger that a brother will not know about his half sister from the same father, and they will inadvertently marry and produce mamzerim (bastards). This text is extremely difficult to comprehend. The rabbis have reason to fear their evil inclination (yetzer hara), but they must also fear their Creator. On the one hand, if we are talking about cohabitation that is not fully halakhically valid, as in the case of an additional wife to the first wife who is legally married to the sage (and is living in a different place), how do we justify these sages' inappropriate deeds? ${ }^{\text {? }} 8$ Perhaps the text is an amoraic documentation of the halakhic approach to temporary marriages of a predetermined length and their annulment at the end of that period (apparently with a get, although opinions are not unanimous). On the other hand, if the text is indeed referring to a temporary marriage, how do we explain this immoral behavior of sages who were already legally married yet took an extra wife for a predetermined period ${ }^{19}$ and made the specific condition of a temporary marriage before the marriage? ${ }^{20}$

Rashi, in his commentary to the texts in Yoma and Yevamot, explains that the words "Who will be mine for a day?" refer to a search for a woman who would agree to be married for one or several

i7 Babylonian Talmud, Yoma i8b, with the parallel in Babylonian Talmud, Yevamot $37 \mathrm{~b}$. Unless otherwise noted, all translations from the Babylonian Talmud in this article are from the Online Soncino Babylonian Talmud Translation. Soncino Babylonian Talmud. Translated into Enlgish with Notes, Glossary and Indices Under THE Editorship of Rabbi Dr. I EpsteIn, posted by Charles Jones, August Io, 20I 5, http://ancientworldonline.blogspot.co.il/20I2/OI/online-soncino-babylonian-talmud.html. Here and throughout the article, acute brackets indicate interpolations found in the translations, and square brackets indicate my interpolations. As noted above, all other translations from the Hebrew are mine.

i8 See, for example, Adiel Schremer, Zahar u-Nekeva Bar’am [Male and Female He Created Them: Jewish Marriage in the Late Second Temple, Mishnah and Talmud Periods] 206 (2003), who assumed that the text is not discussing fully legal marriages, because these marriages do not involve normal, day-to-day family life, but "he is renting an escort service for the night." For a similar criticism of the sages' behavior, see A.S. Hershberg, Yofya ve-Hityafuta shel ha-Isha bi-Zman ha-Talmud [The Beauty of the Woman in the Talmudic Period], 4 He-ATID I (I923) ("Even our sages in the Talmud had different notions of modesty and immorality according to the time and the place.”). For a comparison of modesty in the Jewish society of Erez Israel and the lack of modesty in Babylonian Jewish society, see Hershberg, supra, at 4-Io.

I9 Moshe D. Her, Ha-Nisuin mi-Behina Socio-Economit Lefi ha-Halakha [The Marriage from Halakhic-SocioEconomic Perspective], in Mishpahot Beit Yisrael [Jewish Families] 37, 40 (1976), together with the sources he cites in n.I6.

20 For a discussion of the extent to which the early rabbinic authorities took the text literally to mean a full marriage, including marital relations that could end in pregnancy, see tosafists in BABYLONIAN TALMUD, Yevamot, s.v. "Yihudi." For a rejection of this view, see, for example, Hagahot Maharam and Yissachar EIlenberg, Resp. Beer Sheva ch. 26 (2004). For further discussion, see Ben-Zion M. Uziel, Resp. Mishpatei Uziel, Even ha-Ezer 2:45, at $132-34$ (1964). 
days while the sage is in town, after which they would separate. ${ }^{2 \mathrm{I}}$ It would seem that the text is referring to a full marriage requiring a divorce procedure to end it. On the other hand, the Talmud suggests - and such suggestions sometimes have the status of a halakhic ruling - that the woman is not fully married but has simply been designated for him. Indeed, many of the early rabbinic authorities followed the opinion of the tosafist RI- (Rabbi Yitzhak ben Shmuel the Elder), who asserts that the text is not referring to a proper marriage, but a situation in which a woman is allocated to the sage de jure but not de facto. The purpose was to ensure that the sages would be able to satisfy their sexual needs, ${ }^{22}$ but the marriage was not a full marriage that requires a get. ${ }^{23}$ Similarly Yitzhak bar Sheshet Perfet (Rivash, ch. 398) writes as follows:

But it would seem that this is only a designation; in other words a woman is selected and makes preparations to marry the rabbis if the rabbis should wish to do so. The rabbis would not marry them; but would make a condition to marry them should they [the rabbis] so desire. This would calm their sexual urges, as a woman was available in the town and was prepared to marry them should they so wish. ${ }^{24}$

Isaiah the Elder of Terani (Rid) holds a similar view. He writes that this is not a full marriage with the right to have intercourse, but only permission to be with the woman: "One may claim that they were not alone together in one bed, but were together in the same house; he remained with the men and his wife remained with the women." 25 One group of early rabbinic authorities is of the opinion that the marriage was a fully legal marriage, but without sexual intercourse. Therefore, the sage would set down a condition at the time of the marriage that the marriage is valid only while he is in town, and when he leaves town, the woman will agree to a divorce. According to Rabbenu Hananel, this is a fully legal marriage that requires a get to dissolve it before the sage leaves town. He writes, "So, who will be mine for a day and when I leave the place I will divorce her... . How can you say that they had intercourse with her. They did not [have intercourse] but only enjoyed her company." ${ }^{26}$ Meiri, in his work Bet ha-Behirah, explained the Talmudic text as follows:

This describes how one of our sages would marry a woman temporarily in every town in which he stayed, even where his stay was as short as one day, in order to control his sexual urges, and he would make a condition that he was marrying her for a short period in order that she should agree to a divorce afterwards, and no sexual relations took place. They would merely occupy the same house, so that he should not feel the lack of a wife and could more easily resist his urges. ${ }^{27}$

Some rabbinic authorities tried to dismiss the problem of the Talmudic text by claiming it to be pure slander and not originally part of the Babylonian Talmud, inserted by a student of one of the

2 I Babylonian Talmud, Yoma i8b, s.v. "Man”; Babylonian Talmud, Yevamot 37b, s.v. "Man."

22 See, for example, the unequivocal statement by Ashtori haParchi, Kaftor vaPerach [Button and Flower] ch. 44 (I994).

23 For further discussion of the difference between Rashi's explanation and that of the tosafists, see Maharsha, s.v. "Yihudi be-Alma." For a summary of the first six opinions presented, see SHLOMO GANZFRIED, LEHEM VE-SIMLA ON the SHulhan ARUKh, Yore De'ah I92:Io (I997).

24 Yitzhak bar Sheshet Perfet, Resp. Rivash ch. 398 (ig68).

25 Isaiah the Elder of Terani (Rid) in his commentary to the BABYLONIAN TALMUD, Yoma I8b.

26 Rabbenu Hananel, Commentary to Tractate Yoma i 8 (I993) (my emphasis).

27 Meiri, in his work Bet ha-Behirah in his commentary to the BabYLONIAN TALmud, Yoma I8b (my emphasis). 
sages who had erred in his ways or wished to mock. ${ }^{28}$ According to Chaim Bloch, the text was inserted by residents of Shekunzib, who were known for their sense of humor. The sages made no such declaration, but rather it was simply a joke by a resident of Shekunzib, in which he incorporated the name of a prominent person. ${ }^{29}$ Other commentators attempted to mitigate the problem of taking a wife in a temporary marriage for a predetermined period rather than conducting an official marriage ceremony with a hupah (the Jewish canopy) and kiddushin (the Jewish betrothal) by defining this deed as pilagshut, whose only purpose was to save these sages from their evil inclinations. Shmuel Shtrason (Rashash), in his commentary to this text in Yoma, explains, "We would explain that he did not marry by means of kiddushin and hupah but retained them for intercourse as a pilegesh [concubine] according to the rulings by Ra'avad and Nahmanides that a pilegesh is permitted to commoners ... A regular marriage requires counting seven days of purity, but this form does not." 30

Yaakov ben Zvi Hirsch Ashkenazi Emden (I698-I776) used this precedent for his famous ruling permitting a man to take a pilegesh, based on these two sages who took women without a bupah and kiddushin. He writes,

It is said in the first chapter of Yoma that when Rav reached Darshish, he announced, "Who will be mine for a day?" People were amazed and asked if he had intercourse with her. I wrote that this proves that a commoner is allowed to take a pilegesh, because it is obvious that a commoner would not write a ketubah (Jewish marriage contract) for one day, but would take her as a pilegesh and he does not have to write ketu$b a b$ for her, therefore there is no problem that he is not allowed to remain with her without a ketubah. The intention is that a man should not hold his wife in contempt and be able to divorce her easily, and this permanence refers only to taking a wife who requires a ketubah. Since this permanence was explicitly agreed between them, he cannot change the conditions without her agreement. However, in the case of a pilegesh, she has agreed to his conditions. This is obviously the case for those rabbis who were interested in a temporary arrangement for one day and would be leaving the following day. ${ }^{31}$

28 See Yosef Z. Diner (Ritzad), Novellae to Tractate Zebahim Vol. 488 (I999).

29 See Chaim Bloch, Veda ma-SheTashiv [And Know What to Answer] 26-30 (I962). In his introduction he rejects the two suggestions of Moshe LeIter, Zuto SHEL YAM [FloOding OF THE SEA] (I932), that the sages' announcement was intented to eradicate the practice of marrying a woman without following the proper halakhic procedure and to save a man from sinning by instituting preventive measures. He bases himself on a responsum by YITZHAK EtTinger, Resp. Mahariya Ha-Levi ch.r6 (I970), who also found the announcement unclear and puzzling. Shmuel Shtrason (Rashash), in his commentary to this text in Yoma I 8b.

See YaAkov B. Emden, Resp. She’elat Ya'abez 2:I 5 (2004). For a similar scholarly perspective, which concludes that this is a case of pilagshut, see Elman, supra note $\mathrm{I}_{5}$, at I55. For a discussion of the pilegesh in the Bible, see the following references in Hebrew: Yaakov Ariel, Ha-Pilegesh u-Ma'amadah ha-Hilkhati be-Miqra [The Concubine and Her Status in the Bible], 8 MEgadim 57 (1989). Taking a pilegesh was a common practice in Maimonides's day, and he refers to it in various responsa, see Shimon Shtober, Al Shte She'elot she-Hufnu el Rabenu Avraham ben ha-Rambam [On Two Questions That Were Referred to Rabbino Avraham, the Son of Maimonides], 6-7 Shnaton Ha-Mishpat Haivri 399 (I979-I980). For a modern attempt to revive the institution of pilagshut using these precedents, see, for example, Zvi Zohar, Zogiyut Al Pi haHalakha Lelo Hopa veKidushin [Halakhic Positions Permitting Nonmarital Sexual Intimacy], I7 Акдамот г г (2006). Needless to say, this suggestion was strongly criticized, inter alia, by Yehuda H. Henkin, Aharita mi Yeshurena [Who Knows What Will Be Its Fate?], I7 Акдамот 33 (2006); Shmuel Ariel, Pilagshut ena "Haverut" [Concubine Is Not Only Friendship], I7 Акдамот 4I (2006); Michal Tikachinski and Rachel Sperber-Frankel, Tazhiram min ha-Pilegesh [You Should Warn Them from the Concubine], I7 АкDАмот 67 (2006); and Zvi Zohar's response to the objections, in Teshuva le-Magivim [A Response to the Responders], 17 Акдамот 77 (2006). 
Other authorities were of the opinion that this was not a legal marriage in which sexual intercourse is permitted, but rather a marriage for a fixed time that did not include sexual relations but simply serving the husband, such as housekeeping and the like. As explained in a geonic commentary, "There was no sexual intercourse but the woman would serve in the house during the day." 32 Some early rabbinic authorities were of the opinion that the marriage was legal, and there was no need for divorce when the sage left town because the women were available every time the sage returned. 33 Other authorities ruled that the marriage was valid and a get was required in order to abrogate it. According to Avraham min ha-Har ( $\mathrm{I}_{3} \mathrm{I}_{5}$ ) in his commentary to Yevamot, s.v. "le-Yome," we can understand that the text is referring to a valid marriage, which must be dissolved by providing a get: "Who will be mine for a day while I am staying here and I will divorce her. They would do so in every place they visited, even though they already had wives and children. This is the first explanation." 34

Other academic scholars offered some strange explanations in their struggle to understand this puzzling text. Yet all were an apologetic attempt to avoid the obvious meaning. 35 In their opinion, it cannot be deduced from the text that the reference may indeed be to a temporary marriage. Their explanations included the following: Rav wished to do away with the negative custom of a wedding that was conducted without prior matchmaking and therefore asked his fellow citizens to arrange a marriage for him; the act was to counter the evil inclination and to prevent a possible test of a sexual nature, and the sage therefore wished to marry in order to neutralize his evil inclination; ${ }^{36}$ due to the halakhic prohibitions of being alone with the wife of the innkeeper and questions of kashrut regarding the food, together with problematic relationships with the sages' wives, the sages preferred to take an extra wife, if "she [the extra wife] agreed" ${ }^{37}$; the Persians used to offer a woman to important guests who arrived without their wives, and therefore the sages made the fictitious announcement that they were looking for wives in order to prevent the Persians from sending them a Persian woman.

Further explanations include that the announcement, "Who will be mine for a day?" is not a search for a woman with whom to conduct marital relations, but a search for a place to stay while in the town; this is neither a public declaration nor a search for a wife, but a halakhic statement or popular saying briefly alluding to the issue of sexual intercourse on the Day of Atonement; these statements are a result of problems between the sages and their wives, hinting

32 Quoted in Otzar ha-Geonim [The Treasure of the Geonim] on Babylonian Talmud, Yoma i8b (Benjamin M. Levin ed., I928).

33 These opinions were summarized by Uziel in his responsa, see Ben-Zion M. Uziel, Resp. Piskei Uziel be-She'elot Ha-ZMan ch. 54 (1977). For a similar approach, see, for example, Moshe Feinstein, Dibrot Moshe on Babylonian TALMUD, Yevamot $82 \mathrm{n} .68$ (I979), who reached the conclusion that there was no issue of divorce, since the woman would be called for every time the sage returned to the city, which occurred frequently.

34 Avraham min ha-Har in his commentary to Yevamot, s.v. "le-Yome" (Arieli ed., 2000) (my emphasis).

35 See Simeon Lowy, The Extent of Jewish Polygamy in Talmudic Times, 9 Journal of Jewish Studies I I 5 , I 23 (I958); Isaiah Gafni, Yehudei Bavel beTkufat haTalmud [The Jews of Babylonia in the Talmudic Era] 272 (I990).

36 See, respectively, the following sources in Hebrew: Ben-Zion M. Uziel, Man Havya le-Yom [Who Will Be Mine for a Day?], 99-IOO HA-PoseK 1979 (I948); BLOCH, supra note 29, at 26. For a rejection of this explanation, see Margaliot, infra note 38 . It is interesting to note that Chaim Berlin, Resp. Nishmat HAyYim ch. I42 (2008), raised this possibility but ultimately rejected it.

37 See comment on Uziel by Hillell Posek, editor of HA-Posek, in Man Havya le-Yom [Who Will Be Mine for a Day?], HA-PoseK I979, at I 542 . 
that they could take additional wives, or perhaps the wives' behavior may have been the result of these declarations..$^{8}$

Before presenting a novel explanation of the Talmudic text, and what I consider an interesting approach, which I discuss in some detail below, I offer the following discussion of an ancient and unique Muslim form of marriage that does not appear to be relevant to our discussion and is most certainly antithetical to the spirit of Judaism but might, however, shed light on the ancient Persian-Babylonian roots of temporary marriage, which are reflected in the Babylonian Talmud.

\section{THE SHI'ITE TEMPORARY MARRIAGE FOR PLEASURE (زواج متعة - MUTA)}

\section{General}

The Shi'ite temporary marriage- $-m u t a-$ is a temporary marriage whose main purpose is pleasure. When the marriage contract expires, the woman is available again for marriage to anyone, without this entailing any formal divorce procedure. This form of marriage has been discussed in some detail in the scholarly literature 39 and has even been the subject of a film that examines this unique type of marriage. $4^{\circ}$ Traditionally, the muta marriage has been one of the points of contention between Sunni and Shi'ite Islam; it was permitted by the latter but categorically forbidden by the former. ${ }^{4}$ It seems that today, the situation is reversed, and those who previously forbade the marriage tend to permit it, while those who used to permit the marriage now raise objections to it in order to limit its prevalence..$^{2}$ There are those who claim that Shi'ite Islam tended to permit it because the Shi'ites were a persecuted minority, fleeing from place to place, and it was necessary to develop a form of marriage that was suitable to this way of life.43 Other scholars claim that this was the reason Shi'ite ideologists clothed the institution in holiness, ${ }^{44}$ to the extent that some imams have ruled that a person who has not tried this form of marriage has not completely fulfilled the precepts of Islamic marriage. 45

One of the interesting religious justifications for this Shi'ite approach is the Sunni opposition. Any Shi'ite who enters into such a marriage gains spiritually, especially if he marries one of

38 For a review of the last four explanations, and several rejections of these explanations, see the following research in Hebrew: Reuven Margaliot, Man Havya le-Yoma [Who Will Be Mine for a Day?], 2I SiNAi 176 (I947) (explanations); Uziel, supra note 36 (rejections); Shmuel Kraus, Man Havya le-Yoma [Who Will Be Mine for a Day?], 22 SinAI 299 (I948) (rejections); Ben-Zion M. Uziel, Man Havya le-Yoma [Who Will Be Mine for a Day?], IOI-02 HA-PoseK I 554 (1949) (rejections); Noah Aminah, Man Havya le-Yoma [Who Will Be Mine for a Day?], 8I SINAI I69 (1977) (rejections). For further discussion, see YaAkov Neusner, A History of the Jews in Babylonia Vol. 2 I30 (I966).

39 See Shahla Haeri, Law of Desire: Temporary Marriage in Shi' Islam (i989); Abu'l-Qasim Gourji, Temporary Marriage (Mut'a) in Islamic Law (i987); Arthur Gribetz, Strange Bedfellows: Mutat Al-Nisa And Mutat Al-HajJ: A Study Based on Sunni and Shil Sources of Tafsir, Hadith and Fiqh (I994).

40 The film, Zu'aj al-Mat'a (The Mistaken Marriage), according to Behor, contributed to the cessation of such marriages, which were far too common in Egypt in the I970s. See BeHor, supra note 2, at 275 n.4I.

4I This conclusion is based on Ignac Goldziher, Introduction to Islamic Theology and Law 209 (Andras \& Ruth Hamori trans., I98I). For an exhaustive discussion of the differences between the Sunni and Shi'ites, see HusaIN M. Jafri, The Origins and Early Development of Shi'a Islam (i979).

42 See AbD Al ATI, supra note 2, at 108-09 (1977).

43 For a discussion of this claim, see Abd al Ati, supra note 2, at Io6.

44 See Goitein \& Ben Shemesh, supra note 2, at I 29.

45 "The believer is only perfect when he has experienced a muta." The source for this claim is AL-HuRR AL-'ĀMILI,

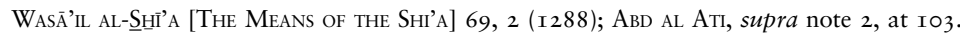


Muhammad's descendants. It would seem that ignoring the prohibition to the muta marriage laid down by Caliph Omar in the seventh century CE would probably give God pleasure according to the Shi'ite approach, particularly in view of Sunni opposition to it. ${ }^{46}$ This form of marriage is built on mutual agreement (lazzim), established by the marriage proposal and its acceptance ( $k a b \bar{u} l$ and $\bar{i} \underline{d} \bar{j} b$ ), and requires specifying the time span for the marriage (adjal), which may vary from one day to several years, but no more than ninety-nine years. It is not clear what happens to an agreement that has no clearly defined time span. Does it become a standard marriage or is the marriage contract null and void? 47 The contract must also include the exact payment to be made to the woman who agrees to these conditions (a $\underline{j} \underline{j} / \mathrm{mahr}$ ), otherwise the contract is null and void. $4^{8}$

The muta marriage was customary for traveling men, but not exclusively, and it permitted them to take additional wives over and above their four legal wives. The muta marriage expires at the agreed upon time; however, the groom can terminate the agreement at any time, whereas the bride cannot terminate it at all. Thus, in these temporary marriages, women are treated like the object of a lease: the man can discard them at any time, thus breaking the contract, and thus giving the male a lot of freedom. ${ }^{49}$ However, a muta marriage cannot be extended, even by mutual agreement. Instead, a new marriage ceremony and bridal contract is required prior to the expiry of the original contract. This marriage does not place any obligations on the husband with regard to his wife, not even food and lodging, and there are no rights of inheritance on either side. However, according to some opinions, if the marriage contract contains a specific stipulation, it must be legally validated. $5^{\circ}$

\section{The Ancient Roots of the Shi'ite Temporary Marriage}

The muta form of marriage was common among Arabs as early as the fourth century CE. ${ }^{\text {I }}$ It appears that muta marriages were known in the Jahiliyya period (the time period before Muhammad received his first revelation of the Qur'an) and were also very common in Eritrea. ${ }^{2}$

46 See HaERI, supra note 39, at I67; Kristen Cherry, Marriage and Divorce Law in Pakistan and Iran: The Problem of Recognition, 9 Tulsa Journal of Comparative \& International Law 319, 339 (2001).

47 See Jane Khatib-Chahidi, Sexual Prohibitions, Shared Space and Fictive Marriages in Shi'ite Iran, in WomEN AND Space: Ground Rules and Social Maps i i2, i26 (Shirley Ardener ed., i98 I); Amal J. Nasir, The Islamic Law of Personal Status 59 (1990); Tamilla F. Ghodsi, Tying A Slipknot: Temporary Marriages in Iran, I 5 Michigan Journal of InTERnATIONAL LAW 645, 667-68 (I994).

48 See HaErI, supra note 39, at 5 I-53. For a review of contract law from both the practical and procedural aspects, which affect family law, and where this form of marriage differs from the standard marriage, see IL'IA P. Petrushevsky, Islam in Iran I44, 23 I (Hubert Evans trans., I985); Cherry, supra note 46, at 336-40. For a review of the relevant practical and procedural Muslim requirements regarding the validity of this contract and the attempt to merge the two types of marriage, see ABD AL ATI, supra note 2, at Iо8-09.

49 See Edna Boyle-Lewicki, Need World's Collide: The Hudad Crimes of Islamic Law and International Human Rights, I 3 New York International Law Review 43, 68 n.I 16 (2000).

50 For a more exhaustive discussion, see Heffening, supra note 4.

5 I See, for example, Ammianus Marcellinus, xiv, 4, cited by Judah B. Segal, Arabs in Syriac Literature before the Rise of Islam, 4 Jerusalem Studies in Arabic and Islam 98 ( 1984 ). Although, I should point out that it is difficult to connect the phenomenon that he discusses with the Islamic muta because in those days the woman would bring a tent and spear to the man she was interested in, and after a certain time she was allowed to leave him. For a review of the roots of the institution of marriage in early Islam, see GerTRUde H. STERN, MARRIAGE IN Early Islam i 55 (i939); Joseph Schacht, The Origins of Muhammadan Jurisprudence 266 (i950); Schacht, An Introduction to Islamic Law i63 (1964).

52 See Carlo Conti Rossini, Principi di diritto consuetudinario dell'Eritrea [Principles of Common Law of Eritrea] I 89, 249 (I9I6). 
Thus, the institution has a long history prior to its adoption by Islam. 53 It should be pointed out that in addition to the sources already mentioned, there are references to muta marriages in the fourth century, not only in the Arabian Peninsula, but also in Egypt. ${ }^{54}$ It is, however, most common nowadays in Iran (previously Persia), which was governed by Islamic law after the Arab conquest and the death of Muhammad in 632 CE. It was relatively easy for different peoples to accept Islamic religious rule, as it offered equality and tolerance of the state that existed prior to the conquest. 55

The term muta does not appear in the Qur'an. Some commentaries suggest that there is a verse in the Sura about women (4:24) that contains a reference to this concept: "Pay women who give you pleasure whatever you have promised." ${ }^{56}$ It is generally accepted that Muhammad's warriors were allowed muta marriages when engaging in holy wars of jihad away from home. ${ }^{57}$ There are also a number of recorded cases of muta marriages at the beginning of Islam. In the hadith Sahih Al-Bukhari collection, for example, there are four references to a muta marriage. In one case, permission for it was issued by Muhammad himself: "We were in the army and a messenger arrived from Muhammad and said: Muhammad agreed that you should enjoy yourselves, so enjoy [muta marriages]." ${ }^{8} 8$

Later on, muta marriages were forbidden among Muslims. It is not clear when Muhammad forbade these marriages, but all Sunni authors of the hadith agree that muta marriages were forbidden. On the other hand, Shi'ite sages claim that everyone knows that these marriages were permitted, and in the absence of evidence to the contrary, the practice is still permitted. An example of the dispute over when the marriages were prohibited may be found in the book Sunan Al-Darimi, which suggests different dates for Muhammad's prohibition. The first source is, "he said: Muhammad forbade the muta marriage in 629." 59 The second source: "Muhammad forbade the practice of muta marriages and marriages between blood relations in the Hibar year."60 However, other scholars claim that muta marriages were still practiced in the eleventh to thirteenth centuries, at the time of the Caliph Abu Bakr.

53 For a discussion of this claim, see William Robertson Smith, Kinship \& Marriage in Early Arabia 82 (i903).

54 See Edvard A. Westermarck, The History of Human Marriage 267-88 (i922); George A. Wilken, Das Matriarchat (Das Mutterrecht) bei den alten Arabern [The Matriarchy or Mother-Right among the Ancient Arabs] 2I-22 (i 884); Ludwig Mitteis \& Ulrich Wilcken, 2 Grundzüge und Chrestomathie der Papyruskunde [Basics of Papyrology, with an Anthology of Sources], part i, at 203-o8 (I9I2); Eugenio Griffini, Corpus Iuris di Zayd Ibn 'Ali [The “Corpus Juris” of Zayd Ibn Ali ] 327 (i9i9).

55 See Iran: A Country Study i i (Helen Chapin Metz ed., I989).

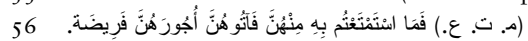

57 See Abdur Rahman I. Doi, Shari’ah: The Islamic Law I 5 5-56 (I984).

58 الا: كنا في جيش فأتانا رسولرسول اله صلعم فقال إنه قد أُذِن لكم أن تستمتعوا، فاستمنِعوا. See MuHAMmad IBN IsMAIL AL-BukHARI, SAHIH al-Bukhari, The Book of Marriage, no. 5i i7-5i i8; Leone Caetani, Annali Dell'islam [The Annals of Islam] 478 (I972).

خبرنا محمد بن يو سف، حثثا ابن عيينة، عن الزهري، عن الربيع بن سبرة الجهني، عن ابيه، قال نهى رسول الله. صلى الله عليه وسلم عن نكاح المتعة عام الفتح 59 الفئ “The opening year" is the year when Mecca was opened to Muslims (629). In this year, Muslims were allowed to enter the Haram in Mecca for the first time.

حدثا محمد، حدثني ابن عيينة، عن الزهري، عن الحسن، وعبد الله، عن ابيهما، قال سمعت عليا، يقول لابن عباس إن. رسول الله صلى الله عليه وسلم نهى عن 60 AbDalla BEN AbDalrahman AL-DARAmi, SANAN AL-Daram [The TradiTIONS OF AL-DARAM] VOL. 264 (I966). For a list of sources, see Heffening, supra note 4. 


\section{Contemporary Temporary Marriage $e^{6 I}$}

There is comprehensive early eighteenth-century documentation of marriages for a limited time period that were brought for discussion to the Qadi in Sounan (Șan'â'), in Southern Arabia. ${ }^{62}$ In Mecca, both in modern and ancient times, the Sunnis conducted marriages for limited periods of time. These marriages were official and valid, but incorporated the divorce formula (tala $k$ ) for the time when the marriage would expire. This combination produced the same type of marriage as their Shi'ite brethren's muta marriage. ${ }^{63}$ Documentation also exists about the practice of these marriages into the beginning of the twentieth century in Eastern Syria at Deir ez-Zor, ${ }^{64}$ as well as for the practice of this type of marriage among the Falashas in Ethiopia today, where it is known as a "soldier's marriage." It is one of three types of Falasha marriages for a limited period of time which is mutually agreed upon by the couple. ${ }^{65}$

There are recent claims that temporary marriage has been used to disguise prostitution in some Middle Eastern countries. Others argue that a temporary marriage is morally superior to the free "and decadent" male-female relationships in modern Western societies. Others maintain that such marriages are becoming newly popular among the majority Shi'ite population in Iraq and they are becoming a convenient way of effectively legalizing prostitution and concubinage, with muta contracts for as short as an hour being upheld by Shi'ite clerics. ${ }^{66}$

In recent years, there have been a small number of civil-secular court rulings regarding muta marriages. It is perfectly clear, even from this small number of examples, that these marriages are not recognized, even as putative marriages, as demonstrated in a ruling in the United States in re Marriage of Vryonis. ${ }^{67}$ The case involved an Iranian woman in an unhappy muta marriage who sued for alimony. Her so-called husband denied the existence of any such marriage. In spite

6I For a review of muta marriages in modern Islamic law, see, for example, Sachiko Murata, Temporary Marriage IN Islamic LaW (2015); Brooke D. Rodgers-Miller, Out of Jahiliyya: Historic and Modern Incarnations of Polygamy in the Islamic World, i I William \& Mary Journal of Women \& LaW 54I (2005); Dan E. Stigall, Iraqi Civil Law: Its Sources, Substance, and Sundering, i6 Journal of Transnational Law \& Policy I, 52-53 (2006); Haider Ala Hamoudi, Sex and the Shari'a: Defining Gender Norms and Sexual Deviancy in Shi'i Islam, 39 Fordham INTERNATIONAL LaW Journal 25, 4I-45 (20I5).

62 See, for example, Alexander D. Hamilton, A New Account of the East-Indies Vol. 2 5 I (I732), first mentioned by WILKEN, supra note 54 , at I9.

63 See documentation in C. Snouck Hurgronje, MekKa [Mecca] I 56 (I 888); 6 C. Snouck Hurgronje, Verspreide Geschriften [Collected Works] I 50 (I923).

64 See documentation in Victor Müller, En Syrie aveC les Bédouins: les tribus du déSert [IN Syria with the Bedouins: The Tribes of the Desert] 23 I-32 (I93I).

65 For a modern discussion of these marriages, see Hiba Basol-Taha, Nissuin Zmaniim baIslam meNekudat Mabatam Shel haHalakhah haMuslemit, haHuk vehaNormot haHevratiot [Temporary Marriage in Islam from the Perspectives of Shari'a, Civil Law and Social Norms] (M.A. thesis, Bar-Ilan University, 2008); Barbara Watson Andaya, From Temporary Wife to Prostitute: Sexuality and Economic Change in Early Modern Southeast Asia, 9 Journal of Women's History i I (I998).

66 See Olga Voinarevich, A Fairy Tale Interrupted: The Long-Term Impacts of Child Marriage in Yemen and the Necessary Adjustments to Both Local and International Laws to Stop the Practice and to Protect Voiceless Child Brides, I6 Rutgers Race \& Law Review 203, 213 n.65 (2015); John Witte \& Joel A. Nichols, Marriage, Religion, and the Role of the Civil State: More Than a Mere Contract: Marriage as Contract and Covenant in Law and Theology, 5 University St. Thomas Law Journal 595, 60I n.27 (2008); Rodolphe J. A. De Seife, Book Review, 42 American Journal of Legal History 84, 86 (i998) (reviewing Muhammad Khalid Masud et al. eds., Islamic Legal Interpretation: Muftis and Their Fatwas); see also Hamoudi, supra note 6I, at $4 \mathrm{I}-45$.

67 In re Marriage of Vryonis 248 Cal. Rptr. 807 (Cal. Ct. App. I988). For a discussion of the ruling see, e.g., Cherry, supra note 46, at 350-5I; see generally, Marjorie M. Shultz, Contractual Ordering of Marriage: A New Model for State Policy, 70 California Law Review 204, 250, 273 (1982). 
of the woman's honest and naïve belief that she was married, the court ruled that the marriage was invalid. The reasons for the ruling were basically procedural, since the marriage was not compatible with California civil law. With regard to the marriage itself, there were no witnesses, no written proof, and no cohabitation. Therefore, there was absolutely no basis for the claim that there had been a marriage. A muta marriage was also addressed in Canadian law in the case of Y.J. v. N. $J$, where the court discussed the question of custody of a five-year-old Muslim girl born of a muta marriage, which was her father's second marriage. Again, the Canadian civil courts ruled that the marriage was invalid. The court did not relate to the religious aspects of such marriages, including the girl's legitimacy. ${ }^{68}$

\section{Shi'ite Temporary Marriage in Rabbinic and Karaite Halakbic Sources}

The negative opinion of the sages regarding muta marriages is already apparent in geonic literature. The first to express an opinion in this regard was Saadia Gaon (882/892-942). In his commentary to the Pentateuch, he notes several times that the prohibition of the kedeshah refers to a muta marriage, and the muta marriage is therefore a biblical prohibition. ${ }^{69}$ This opinion is found in the Cairo Genizah manuscript version of his commentary to Deuteronomy 23:I 8.70 In his discussion of prostitution, Saadia Gaon places it in the first, most lenient category, as explained below (translated from the Arabic):

The first category is a marriage for a limited period, for a woman who agrees to the marriage is called a kedeshah, as in the case of Tamar, the daughter-in-law of Yehudah. And it is written, "There shall be no harlot [kedeshab] of the daughters of Israel," a warning to both the husband and the wife. And why is it in the first category of forbidden marriages? Because it is a marriage with a ketubah and witnesses and kiddushin. The prohibition applies only because of the woman's situation after the termination of the marriage. ${ }^{71}$

Similarly, in a fragment from the Kaufmann manuscript of Saadia Gaon's Sefer ha-Mitzvot, which was found in the Cairo Genizah, he writes: "It is prohibited for a man to marry a woman

68 Y.J. v. N.J., (1994) O.J. No. 2359. See also In re Marriage of Dawley, 55 I P.2d 323 (Cal. I976), and more recently, In the Matter of the Marriage of Soleimani, 20I2 WL 3729939 (Kan. Dist. Ct.). For a detailed discussion of the rulings in the American and Canadian courts, see Shahnaz Khan, Race, Gender, and Orientalism: Muta and the Canadian Legal System, 8 CANAdian Journal OF Women \& LaW 249, 254-57 (I995); Pascale Fournier, The Erasure of Islamic Difference in Canadian and American Family Law Adjudication, ro Journal of Law \& Policy 5 I, 5 I-59 (200I). For a discussion of Western court rulings on Muta marriages, see Ann Laquer Estin, Embracing Tradition: Pluralism in American Family Law, 63 Maryland Law Review 540, 565 n.I 53 (2004); Safiya Ghori, The Application of Religious Law in North American Courts: A Case Study of Muta Marriages, Io Journal of Islamic Law \& Culture 29, 37-40 (2008).

69 See, e.g., his commentary on Genesis, 38:1 $5,2 \mathrm{I}-22$, where the term kedeshah appears in the story of Judah and Tamar, and he translates it using the root "muta." In his commentary to Deuteronomy 23:18, "There shall be no harlot (kedeshah) of the daughters of Israel, neither shall there be a sodomite of the sons of Israel," he uses a similar translation, and Zucker notes that the translation would thus read, "There shall be no temporary marriages among the daughters of Israel." Infra note $7 \mathrm{I}$, at 477-78.

70 See Moshe Zucker, Al Tirgum Rasag la-Torah: Parshanut, Halakha u-Politika be-Tirgum ha-Torah shel Rabbi Sadya Gaon: Te’udot u-Mehkarim [On the Commentary of SaAdya Gaon to the Torah] 477-78 (I959); see also Yosef Kapach, Perushe Rabbenu Sadya Gaon al ha Torah [The Commentaries of SaAdya Gaon to the Torah] I80 n.3 (I994).

7 I See Zucker, supra note 70. 
in a muta marriage, or for a woman to be married [in a muta marriage] for both of them are bound by "There shall be no kedeshah of the daughters of Israel."” 72

Saadia Gaon's consistent approach raises two questions, one related to the content, and the other, technical. In both his commentary to the Pentateuch and in his halakhic writings, Saadia Gaon wants to prove that the prohibition against a muta marriage has the status of a biblical prohibition. According to Moshe Zucker, this approach is not indisputable. According to Jewish halakhic sources, marriage for an agreed period is legal and valid, and according to most authorities, may be dissolved only by means of a get, as demonstrated in my detailed discussion of Babylonian and Palestinian Talmudic sources. Thus, if the status of this woman who has completed a marriage for a fixed period of time and remarries without a get from her first husband is the same as the status of an unmarried woman, the second marriage is permitted, as we have seen in the case of "Who will be mine for a day?" But if at the end of a temporary marriage without a get, this woman's status is the same as that of a married woman, then in effect she is still married to her first husband and now faces the more serious problem of being an adulteress, not a kedeshab (prostitute). ${ }^{73}$

In addition, Professor Eliezer Schlossberg (Department of Arabic, Bar-Ilan University) pointed out to me that this explanation of Saadia Gaon is extremely difficult to understand, because he interprets the Bible's general and sweeping prohibition of a kedeshab as referring to a very particular type of marriage that, in his day, was practiced only among Shi'ites. A possible explanation for these two points, one relating to the content, and the other, technical, is offered by Haim Z. Hirschberg (Department of Jewish History, Bar-Ilan University):

Zucker concludes that Rabbi Saadia Gaon's ruling "requires careful analysis” from a halakhic point of view. It seems that one should look for a historical explanation in the customs of Muslim society that influenced certain phenomena in Jewish society. Marriages for an agreed period, which are called muta (pleasure) marriages are permitted in the Shi'a branch of Islam, which has been, and is still followed by the Muslim population of Persia, half the population of Iraq and a large proportion of Muslims in Syria and Lebanon. In Saadia Gaon's time, Isma'ili (extreme Shi'ite) influence increased in North Africa, and reached Egypt. It is conceivable that Jews in Persia, Iraq and Syria were influenced by Shi'ite Islam and demonstrated a more lenient approach to marriages for agreed periods, and left a woman without giving her a get ... Saadia Gaon's intention in translating Deuteronomy 23:I 8 in this way was to warn against those who wished to permit muta marriages. ${ }^{74}$

72 Published by Alexander Scheiber \& Yizhak Hahn, Dapim meSefer haMitzvot leRav Saadya Gaon [(Manuscript) Leaves from Se'adya's Sefer ha-Mitzvot], 28 TARBIZ 48 (1959). For a detailed discussion of these sources, see Mordechai. A. Friedman, haHalakhah Keedot leHayei haMin Etzel haYehudim Shebeartzot haIslam Bimei Habeinaim: Kisuy haPanim veNissuei Mutah [Halakha as Evidence of Sexual Life Among Jews in Muslim Countries in the Middle Ages], 45 Pеамім 89, го0-ог (I99I); see generally, Daniel J. Lasker, Saadya Gaon on Christianity and Islam, in The Jews of Medieval Islam: Community, Society, and Identity i65 (Daniel Frank ed., I995); David M. Freidenreich, The Use of Islamic Sources in Saadiah Gaon's "Tafsìr" of the Torah, 93 Jewish Quarterly Review 353 (2003); David H. Frankel, Studies in Saadiah Gaon's Arabic Translations 2I (M.A. thesis, Ohio State University, 20I 2).

73 See ZuCKer, supra note 70 , at 478.

74 Haim Z. Hirschberg, Le-Heker Rav Sadya Gaon ve-Tequfato [The Research of Rav Saadya Gaon and His Period], 3 I TARBIZ 4I 5, 42I (I962). The Islamic influence on halakhah in the Geonic period has been discussed extensively. See, e.g., J. Blumberg, Munahim Mishpati'im Aravi'im mi-Dine ha-Kinyan be-Geonim uve-Rambam [Arabic Legal Terms in the Field of Ownership in the Geonim and in the Rambam], I4-I 5 SHNATON Ha-MishPat Ha-IVRI 6I (1988-1989). In addition to the vivid writing of Gideon Libson in Hebrew, see his seminal research: Libson, Halakhah and Reality in the Gaonic Period: Taqqanah, Minhag, Tradition and Consensus: Some Observations, in The Jews of Medieval Islam: Community, Society, and Identity 67 (Daniel Frank ed., i995), 
Mordechai A. Friedman (Department of Talmud, Tel-Aviv University) adds another dimension by claiming that Saadia Gaon went even further and prohibited marriages for agreed periods even when the woman was given a get at the end of that period. He writes as follows:

It seems more likely that Saadia Gaon was referring to temporary marriages with a get, even though under Shi' ite Islamic law a woman is released from a muta marriage without a divorce. The fact that Jewish sages writing in Judeo-Arabic use a term borrowed from Islamic law does not necessarily mean that the Jewish institution is identical to the corresponding Islamic institution. They were referring to the closest equivalent to the halakhic institution .... It would seem that the influence of the Islamic muta marriage led to the definition of kadesh and kedeshah in this way. The muta marriage was certainly regarded as abhorrent by Saadia Gaon and other sages, including Karaite sages. To them, this was not a marriage, but rather, legalized prostitution ... what is indubitable is that the Jewish leadership regarded temporary marriages as contrary to Jewish sexual ethics ... their abhorrence led them to take extreme measures: using creative hermeneutics, they created a new Torah prohibition. ${ }^{75}$

Indeed a similar approach to that of Saadia Gaon was adopted by Karaites such as Daniel Alkumsi ${ }^{7}$ and David ben Avraham Alfasi, 77 who ruled that a muta marriage is forbidden and is nothing less than prostitution.

\section{A COMMON PERSIAN ORIGIN: A COMPARISON OF THE BABYLONIAN TALMUDIC MARRIAGE AND SHI'ITE TEMPORARY MARRIAGE ${ }^{78}$}

Unlike the variety of problematic explanations of "Who will be mine for a day?" reviewed above, there are scholars who attribute this appeal by the sages to the Persian influence in Babylonia in the

and more extensively, Lisbon, Jewish and Islamic Law: A Comparative Study of Custom during the Geonic Period I-I 5 (2003). See also M. Tirza Mitcham, Sefer ha-Bagrut le-Rav Shmuel ben Hofni Gaon ve-Sefer ha-Shanim le-Rav Yehuda ha-Kohen [The Book of Maturity of Rav Shmuel Ben Hofni and the Book of Years of Rav Yehuda] 68 (1999). For a general discussion of the influence of the surrounding culture on Jewish marriage, see GafNI, supra note 35, at 266-73; Bernard. S. Jackson, How Jewish is Jewish Law?, 55 Journal of JewISH Studies $20 \mathrm{I}$ (2004); Isaiah. M. Gafni, The Institution of Marriage in Rabbinic Times, in The Jewish Family: Metaphor and Memory i3 (David Kraemer ed., I989).

76 See Abu Yusuf Ya'kub al-Kirkisani, Ya'qub al-Qirqisani on Jewish Sects and Christianity: A Translation of "Kitab AL-ANWAR" Book I With Two Introductory Essays (I984). For a similar translation, see Alanuar, at 728, quoted by Zucker, supra note 70, at 478 n.63.

77 See David ben Abraham al-Fasi, Kitāb Jāmi’ al-Alfāz [The Book of Collected Meanings] Vol. 2 54I (I936-I945). These two translations are to be found in Friedman, supra note 72, at IOI-O2.

78 Research on the influence of Persian law on the Jews living under its suzerainty has received attention in recent years. There is a periodical devoted to the subject and several volumes have already been published. The periodical is edited by Shaul Shaked and its name describes its content: Irano-Judaica: Studies Relating to Jewish Contacts with Persian Culture throughout the Ages. Yaakov Elman has devoted a series of articles to the subject: Yaakov Elman, "Up to the Ears" in Horses' Necks (BM Io8a): On Sasanian Agricultural Policy and Private "Eminent Domain,” 3 Jewish Studies, an Internet Journal 95 (2004); Elman, Marriage and Marital Property in Rabbinic and Sasanian Law, in Rabbinic Law in Its Roman and Near Eastern Context 227 (Catherine Hezser ed., 2003); Elman, Middle Persian Culture and Babylonian Sages: Accommodation and Resistance in the Shaping of Rabbinic Legal Tradition, in The Cambridge Companion to the Talmud and Rabbinic Literature I65 (2007); Elman, Acculturation to Elite Persian Norms and Modes of Thought in the Babylonian Jewish Community of Late Antiquity, NETI'OT LEDAVID 3I (2004). In addition to the research by Adiel Schremer, there are a number of works which note the influence of the alien Persian environment on Jewish marriage in Persia: 
early centuries of the Common Era. Marrying a woman for an agreed period, which is problematic according to the modern halakhic conception of marriage, was a well-known practice in the Persian era, at the time that the Babylonian Talmud was compiled. This practice derives from a more general practice of giving objects for a stated period, as "a gift to be returned." This fascinating approach appears in an article by Yaakov Elman (Department of Jewish History, Yeshiva University) in which he claims that the close contact of the Amoraic elite with Persian culture had a considerable influence on religious Jewish law, including the laws of marriage. He bases this conclusion on the fact that two of the most important amoraim in the Talmud openly admit to entering into what were apparently temporary marriages. He writes as follows:

This is so even though two very prominent rabbis, the aforementioned R. Nahman and the first-generation amora Rav, entered into such marriages [temporary marriages] .... This is but one of many indications that the relationship of the Babylonian rabbinic elite to Sasanian culture was much closer than has been supposed ... The entire discussion presupposes that such marriages were contracted by prominent rabbis. ${ }^{79}$

In his article, Elman paints a fascinating picture of the ancient Persian practice of giving articles for an agreed period, with the articles including women. It is therefore not surprising, in his opinion, that this practice was adopted by Babylonian Jews, including the sages. He notes that the need to fight the practice seems to prove the extent to which it had spread and become accepted, both socially and halakhically:

The fact that these traditions continued to circulate with only technical objections raised, rather than objections that go to the heart of the institution, indicates that such temporary marriages had taken deep root within the Babylonian Jewish community .... Though the second explanation by the redactors suggests that the marriage was not consummated then, this was only for technical reasons: no moral opprobrium was attached to such temporary arrangements .... The nexus of the discussions is the potential violation of incest or the rules of impurity, not the impropriety of polygyny or temporary marriage. ${ }^{8 \circ}$

There are scholars who claim that this Persian practice is the basis for the Shi'ite muta, which slowly became an accepted social practice in the Persian-Shi'ite period prior to the emergence of Zoroastrianism. ${ }^{8 \text { I }}$ Indeed, in a later period, the Persian book of rulings (the Sasanian law book) Madayan $i$ Hazar Dadestan, ${ }^{82}$ contains a number of records of temporary marriages in which a

\footnotetext{
Eliyahu Ahdut, Ma'amad ha-Isha ha-Yehudia be-Bavel be-Tequfat ha-Talmud [The Status of the Jewish Babylonian Woman in the Talmudic Period] 57 (Ph.D. dissertation, The Hebrew University of Jerusalem, i999); Michael. L. Satlow, Jewish Marriage in Antiquity (200i).

79 See Elman, supra note I 5, at I4I. See also Zvi Septimus \& Lena Selaymeh, Temporalities of Marriage: Jewish and Islamic Legal Debates, in Talmudic Transgressions: Essays in Honor of Daniel Boyarin 2OI (Ishay Rosen-Zvi et al., 20I7).

80 Elman, supra note I5, at I $5 \mathrm{I}-54$.

8 I See, e.g., Bodil Hjerrild, Islamic Law and Sasanian Law, in Law And the Islamic World: Past and Present 49, 53 (Christopher Toll \& Jakob Skovgaard-Petersen eds., I995); Maria Macuch, Die Zeitehe im Sasanidischen Rechtein Vorlaufer der shi'itischen mut'a-Ehe in Iran? [Temporary Marriage in Sassanid Law: A Precursor of the Shi'ite mut'a-Marriage in Iran?], I 8 ArchaeOlogische MitTEILUNGEN AUS IrAN I 87 (I985); Elman, supra note I 5 , at I 54 ; Adiel Schremer, Nissuin veHakamat Mishpaha beYahadot Bavel beTkofat haTalmud [Jewish Marriage in TAlmudic Babylonia] 28I n.84 (Ph.D. disseration, The Hebrew University of Jerusalem, I996).

82 For more on this ancient legal codex, see generally GEORGE W. CARTER, ZoroAstrianiSM AND JUdAISM (I970); Women in Iran from the Rise of Islam to i 800 (Guity Nashat \& Lois Beck eds., 2003); Jenny Rose, ZOROASTRIANISM: AN INTRODUCTION (2OII).
} 
woman is handed over by her legal husband, or by her father-even though she may be married to another man - for a predefined period of time, or instructions for dealing with the case of a woman who admits that she gave herself to a man to serve as his wife for ten years, and so on. ${ }^{83}$

It seems highly likely that this Persian practice is the source of the Shi'ite muta marriage, and Babylonian Jews, most probably living in this environment, felt the impact of its influence on the structure of Jewish marriage in their community. Scholars such as Salo Baron point out that the institution of temporary marriage was almost certainly influenced by the polygamy that was prevalent in Babylonia ${ }^{84}$ but was foreign to Erez Israel, where it was banned by the Roman authorities. ${ }^{85}$ In all of the above writings, it appears that the Talmud is the only source not deterred by the possibility that the case of "Who will be mine for a day?" involved a temporary marriage for an agreed period despite the fact that this case categorically contradicts the halakhic principle that it is forbidden to take more than one wife, especially when the wives are located in different towns.

It seems fairly obvious that these sages indeed sought wives for short periods of time when visiting towns far from home. The compilers of the two sources related only the technical issues involved, without any implied condemnation of this practice. The other explanation, that temporary marriages are not real valid marriages, is examined by the compilers only from a technical perspective, and there is no discussion of the substantive principles involved. The only question of principle discussed is the fear that these marriages may result in sibling marriages, thus resulting in incest. There is no condemnation of polygamy or of temporary marriages for a limited period. ${ }^{86}$

Thus, scholars such as Isaiah Gafni (Department of Jewish History, The Hebrew University of Jerusalem) have concluded that the Jewish community was influenced by the Persian environment, where temporary marriages were common, and this was the background for the sages' attempt to enter into temporary marriages for an agreed period of time. ${ }^{87}$ According to Zeev Falk, ${ }^{88}$ Rashba may have reversed his earlier opinion - allowing a marriage for a predetermined period, after which the marriage would dissolve itself automatically without any divorce procedure-due to the negative effects of this practice on the structure of the Jewish family, whereby marriage would resemble the muta marriage: "Rashba was perhaps influenced by the disgust of Muslim judges for temporary marriage-muta-also known as renting, ljara, ${ }^{89}$ which they regarded to be closely related to prostitution." 90

83 For early records, see Anahit Perikhanian, Iranian Society and Law, in 3 Cambridge History of Iran 627, 649-50 (Ehsan Y. Sharter ed., I983). Other sources are supplied by Elman, supra note I 5, at I 54, and the sources he cites in $\mathrm{n} .35$.

84 For information on the frequency of polygamy in Babylonia, see Aly-Ahbar Maharezi, La Famille Iranienne [The Iranian Family] I33-34 (I938), together with the different sources cited by GaFNI, supra note 35, at 266-73; Elman, supra note 15 , at I 59-60.

85 For a discussion of this matter, see Salo W. Baron, A Social and Religious History of the Jews Vol. 226 (I952). With regard to the monogamous life of Jews under Roman suzerainty, see Mordechai A. Friedman, Ribui Nashim be-YisRael [Polygamy among the Jews] 28-32 (I986); Elimelech Westreich, Tmorot beMaamad haIsha baMishpat haIvri: Masa Ben Masorot [Transitions in the Legal Status of the Wife in Jewish Law: A Journey among Traditions] (2002) (Consult the references in the index, s.v. "Tnai Monogamia."); Adiel Schremer, How Much Jewish Polygyny in Roman Palestine?, 63 Procedings of the American Academy for Jewish RESEARCH I8I (200I).

86 This is the conclusion of several scholars, such as Her, supra note I9; Elman, supra note I5. See also the sharp criticism of Nissim H. M. Mizrahi, Resp. Admat Kodesh, Even ha-Ezer i:50 (i99i).

87 See GAFN, supra note 35 , at 272-73.

88 See FALK, supra note I.

89 For an explanation of this term, see Noel J. Coulson, A History of Islamic Law i i I (I964).

90 See FALK, supra note I. 
It is of interest that contemporary scholars of Islamic family law in Israel have noted the Persian influence on the muta marriage, ${ }^{9 \mathrm{I}}$ and both Shlomo D. Goitein (The Hebrew University of Jerusalem) and Aharon Ben Shemesh (Tel-Aviv University) have pointed out the possible connection between a muta marriage and the "one day" rabbinical marriage and the influence of Persian culture on the Jewish community in Babylonia. $9^{2}$ Incidentally, even today, muta weddings are common in Persian culture, and it has even been proposed that the muta wedding be incorporated into Iranian law. 93 While the approach today is to make these marriage contracts for long periods, such as ninety-nine years, there are brokers who offer to conduct temporary marriages for traveling Persians, offering this service in any town for even the shortest periods of time. There is a Persian term for this service-ezdevaje sigeb or ezdevaje movaghat-which is translated as a sort of contract. 94

\section{CONCLUSION}

This article explores the common origin of two current, seemingly totally different marriage structures the Babylonian Talmudic marriage and the Shi'ite temporary marriage. As I explain in the opening of this article, the biblical Jewish marriage is very similar to the Muslim marriage. Nonetheless, from then until now, the two faiths, Judaism and Shi' ite Islam, have crafted their preferred marriage structure totally differently. In Judaism, unlike in Islam, marriage is intended to be permanent rather than temporary, and therefore not subject to stipulation, and certainly not annulled without a get. In addition, divorce is not a constitutive judicial decree adjudicated by a judge or a religious authority that ends a marriage.

According to the Written Law, a divorce depends entirely on the willingness of the husband to give his wife a get. All that remains for the rabbinical court is to oversee the husband's handing the bill of divorce to his wife. Although nowadays there are huge differences, it is very reasonable to claim that throughout the ages, at least in Babylonia during the Talmudic era, the second to fifth centuries CE, the Shi'ite temporary marriage was very similar to the Babylonian Talmudic marriage. This is a very important lesson that can be learned from the ancient history of those two

9I See Meron, supra note 2, at 23.

92 See GoITEIN \& Shemesh, supra note 2, at I 29.

93 The muta marriage is still common in Iran, see Ruhollah Khomeini, A Clarification of Questions: An Unabridged Translation of Resaleh Towzin Al-Masael 3 i i (J. Borujerdi trans., i984). There are a number of scholarly works on muta marriages in Iran. Examples of contemporary works include I. K. A. Howard, Mut'a Marriage Reconsidered in the Context of the Formal Procedures for Islamic Marriage, 20 JouRNAL OF SEMITIC Studies 82 (I975); Shahla Haeri, The Institution of Mut'a Marriage in Iran: A Formal and Historical Perspective, in Islam: Critical Concepts in Sociology I 54-72 Vol. 3 (Bryan S. Turner ed., 2003); Haeri, Temporary Marriage and the State in Iran: An Islamic Discourse on Female Sexuality, 59 SOCIAL RESEARCH $20 \mathrm{I}$ (I992).

94 See Edward G. Browne, A Year amongst the Persians 505-06 (i927); i Jakob E. Polak, Persien: Das Land und Seine Bewohner: Ethnographische Schilderungen [Persia: The Land and Its Inhabitants: Ethnographic Sketches] 207-o8 (i 865); James J. Morier, The Adventures of Hajji Baba of Ispahan Vol. 3, chapters 6-8 (I970); i George N. Curzon, Persia and the Persian Question i64-65 (I996). For the practical aspects today of issuing Iranian visas to temporary wives, see U.S. Department of State, U.S. Visa: Reciprocity and Civil Documents by Country, Islamic Republic of Iran, callout box, Marriage, Divorce Certificates (last visited Feb. I2, 20I8), http://travel.state.gov/content/visas/en/fees/reciprocity-by-country/IR.html. 
faiths: through a deep and thorough exploration of the origins of marriage traditions, a commonality of origin is found. 95

\section{ACKNOWLEDGMENTS}

Special thanks are due to Michael J. Broyde, Israel Z. Gilat, and Ronnie Warburg, who provided me with helpful comments while I was writing this article.

95 For such academic projects, see, for example, Jacob Neusner \& TAmara Sonn, Comparing Religions through LaW (I999). 